\title{
Sustainability and short-term profitability in the agri-food sector, a cross-sectional time-series investigation on global corporations
}

\author{
Sebastiano Cupertino, Gianluca Vitale and Angelo Riccaboni \\ Department of Business and Law, Università degli Studi di Siena, Siena, Italy
}

\begin{abstract}
Purpose - This paper aims to investigate whether being sustainable is also profitable for agri-food companies in the short-term.

Design/methodology/approach - The study analysed the impacts of sustainability multiple issues on oneyear lagged return on assets, developing a longitudinal analysis focused on best and worst companies' samples for a timeframe of ten years. Notably, we performed OLS regressions on unbalanced panels data collecting overall 1,760 annual observations from 318 companies. Moreover, we examined the moderating effects of slack resources on the relationship between sustainability and the short-term firms' profitability.

Findings - The results show that the best sustainable companies usually improve future profitability. Conversely, the worst ones should prioritize efforts in specific initiatives (i.e. responsible products, eco-innovation, management and governance commitment to sustainability), which positively affect their profitability and compensate possible short-term financial losses due to CSR strategy execution and sustainable production/supply chain management. Finally, the study found mixed results regarding the moderating effects of slack resources on the scrutinized relationships.

Practical implications - The paper highlights the key environmental, social and governance aspects to be addressed for consolidating and enhancing the virtuous relationship between non-financial and financial performance, distinguishing between best and worst sustainability performers.

Originality/value - This study is among the first that decomposed sustainability in multiple micro aspects (i.e. sustainable strategy, products and processes) investigating the effects of each of them on the short-term agri-food firms' profitability.
\end{abstract}

Keywords Agri-food sustainability, Firms' short-term profitability, Slack resources, OLS,

Moderation effects analysis

Paper type Research paper

\section{Introduction}

Agri-food and beverages (AF\&B) industry clusters anthropogenic activities that strongly affect ecosystem dynamics, economic growth, and social wellbeing (Gangi et al., 2020). However, food systems are facing interconnected challenges in the last decades. The increase in food demand due to world population growth is causing, in turn, severe environmental stress and health diseases (FAO, 2017). Unsustainable food practices affect biodiversity and climate change. Concurrently, the AF\&B industry suffers from inefficiencies due to food losses along supply chains and environmental degradation.

Given this background, it is even more urgent to change the current paradigm on which global food systems are based. To this end, the launch of Agenda 2030 and some recent

(C) Sebastiano Cupertino, Gianluca Vitale and Angelo Riccaboni. Published by Emerald Publishing Limited. This article is published under the Creative Commons Attribution (CC BY 4.0) licence. Anyone may reproduce, distribute, translate and create derivative works of this article (for both commercial and non-commercial purposes), subject to full attribution to the original publication and authors. The full terms of this licence may be seen at http://creativecommons.org/licences/by/4.0/legalcode

Sustainable development and agri-food

sector

Received 15 February 2021 Revised 15 May 2021 Accepted 19 July 2021 
BFJ

123,13

318

international political programs (e.g. EU-Green Deal; EU-Farm to Fork) are fostering a sustainable AF\&B sector transition to address the aforementioned challenges. However, the full business shift towards sustainability is still weak due to the short-term firms' profitability losses. Indeed, integrating environmental, social and governance (ESG) factors to boost sustainability in business activities needs to rethink corporate purpose, redesign the management system, and allocate financial resources. Accordingly, such a corporate change could penalize firms' profitability shortly, leading managers to find trade-offs that minimize tensions between financial and non-financial performance. The interaction between ESG issues and corporate financial performance (CFP) is a long-standing debated topic in management literature. Scholars have long questioned how much it pays to be sustainable, even though studies have produced conflicting evidence so far. A stream of literature (e.g. Fisher and Sawczyn, 2013; Orlitzky et al., 2003; Waddock and Graves, 1997), embracing the Good Management Theory, argued that being sustainable induces higher future CFP. Conversely, other scholars (e.g. Brammer et al., 2006; Hillman and Keim, 2001; López et al., 2007) following Shareholders Theory insights found that sustainability is detrimental for subsequent CFP. Moreover, despite such a flourishing debate, the relationship between sustainability and CFP is still under-investigated in the AF\&B context which distinguishes for critical ESG issues (Nirino et al., 2019; Gangi et al., 2020). Therefore, the present study, considering a period of ten years, performed a cross-sectional time-series analysis to deepen whether and how prior ESG performance (ESGP) affect future CFP. We used a sample of 318 global AF\&B companies, distinguishing it between top and bottom ESG performers according to Eikon Refinitiv's overall sustainability score. Furthermore, since sustainability goes through several aspects, we focused on AF\&B ESG specific topics (i.e. corporate strategy, products, and processes) investigating the ESGP-CFP link. Notably, we correlated peculiar ESGP to these identified nonfinancial issues assessing their impacts on CFP, demonstrating which of them affect shortly the firms' profitability. Contextually, we tested whether slack resources produce moderating effects on the investigated relationships. The paper is structured as follow: Section-2 Theoretical Background; Section-3 Data and Method; Section-4 Results and Discussions; Section-5 Conclusions.

\section{Theoretical background and research hypotheses}

Does it pay to be sustainable? This dilemma has been challenging management researchers (e.g. Orlitzky et al., 2003; Waddock and Graves, 1997) for at least 30 years, but no univocal evidence has been found regarding the impact of sustainability performance on firms' profitability (Morioka and Carvalho, 2016). The literature on the relationship between sustainability and CFP is mainly divided between scholars who supported a positive impact of sustainability issues on firms' profitability (e.g. Fisher and Sawczyn, 2013; Orlitzky et al., 2003; Waddock and Graves, 1997) and scholars who found a negative relationship (e.g. Brammer et al., 2006; Hillman and Keim, 2001; López et al., 2007). The conflicting results found in the literature suggest that the link between sustainability and firms' profitability is far from being fully understood and it needs to be further investigated. The AF\&B sector is undoubtedly bound to sustainability, given its significant impacts on both social and environmental issues (Gangi et al., 2020). Considering this, it becomes even more relevant to understand the effect that sustainability issues can have on future AF\&B companies' profitability. Despite this, the topic of "how much it pays being sustainable in the AF\&B sector" has only recently received the attention of scholars which also found mixed results (e.g. Gangi et al., 2020; Nirino et al., 2019). Accordingly, Gangi et al. (2020) found that food companies' engagement in corporate social and environmental responsibility is a positive predictor of improved profitability. Similarly, Acar et al. (2019) found that social and environmental sustainability issues increase operational performance. Broccardo and Zicari (2020), considering a sample of 794 Italian wine firms, found that firms implementing sustainable 
activities presented better economic indicators. Despite this, Broccardo and Zicari (2020) also found that firms that are sustainability-oriented may be reluctant to reduce costs. On the other hand, Wiek and Weber (2014), referring to the USA context, pointed out that sustainability-oriented food companies are less able to attract financial capitals than other businesses (such as fast-food and large-scale industrial food production) that are more profitable but also tend to produce detrimental social and environmental effects. Lastly, Nirino et al. (2019) found mixed results showing that social outcomes positively impact firms' performance, while environmental outcomes showed insignificant or non-positive effects. Considering this background, we aim to shed lights on the possible effects that sustainability can have on future $\mathrm{AF} \& \mathrm{~B}$ companies' financial performance, focusing on a short-term perspective. Accordingly, we formulate the following hypothesis:

$H 1 a / b$. Sustainability positively/negatively affects AF\&B firms' performance in the short-term.

Focusing on the relationship at H1, several studies found that slack resources can play a key role in enhancing both CFP (e.g. Agusti-Perez et al., 2020) and ESGP (e.g. Xu et al., 2015). Slack resources represent the cushion of actual or potential resources which allows an organization to adapt to internal and external environment changes fostering strategic adjustments to achieve organizational goals (Bourgeois, 1981; Li et al., 2017). Scholars widely focused on the potential effects of slack resources on both CFP and ESGP, nevertheless few studies considered slack resources as moderating variables of the relationship between sustainability and financial performance, finding mixing results. Accordingly, Li et al. (2017) found that slack resources negatively moderated the relationship between corporate environmental responsibility and CFP. Conversely, Lin et al. (2019) found that financial slack resources positively moderated the financial and non-financial performance interaction. Considering the above background, we aim to deepen the moderating role of slack resources on the link between AF\&B companies' ESGP and CFP. Therefore, we propose the following hypothesis:

$H 2 a / b$. Slack resources positively/negatively moderate the relation between corporate sustainability and financial performance in $\mathrm{AF} \& \mathrm{~B}$ companies.

The above theoretical assumptions are about the general impact of sustainability on CFP. Nevertheless, sustainability is a complex topic that encompasses numerous business aspects. Therefore, in analysing the impact of sustainability on firms' profitability, it is appropriate to consider its several components and analyse the impact of each of them on firms' CFP. This is what we put forward in the following paragraph.

\subsection{Translating sustainability in the $A F \& B$ sector}

In the AF\&B sector, sustainability goes through several aspects such as the execution of sustainable strategies (Coppola and Ianuario, 2017), the production of sustainable products (Ingenbleek, 2015), the implementation of sustainable processes (Augustin et al., 2016), and the responsible management of the supply chain (Maloni and Brown, 2006). In the following lines, these aspects will be deepened, formulating the appropriate hypotheses. For AF\&B companies, producing healthy foods is a key driver to improve human health (FAO, 2017). Nevertheless, producing healthy food is costly and, often, the consumers are not willing to pay premium prices for sustainable food thus preferring the cheaper mainstream alternatives (Ingenbleek, 2015). This could lead companies that offer sustainable products to lower earnings since the market may not reward the choice to invest in sustainable products. This prompted us to formulate the following hypothesis.

$H 3 a / b$. Sustainable products have positive/negative impacts on AF\&B companies' profitability in the short-term.
Sustainable development and agri-food sector 
BFJ

123,13

One of the most debated topics in the management literature is whether sustainabilityoriented strategies improve or weaken firms' profitability especially in the short-term. Following Friedman (1970) doctrine, some scholars (e.g. Boyle et al., 1997; Folajin et al., 2014) found that sustainability-oriented strategies can harm CFP. Conversely, other studies emphasised the positive effects that sustainable strategies can have on the future firms' profitability and growth (e.g. Bodhanwala and Bodhanwala, 2018; Freeman, 1984; McWilliams et al., 2006). Anyhow, there is no doubt that sustainable strategies have an impact on CFP. Accordingly, we deepen such impact in AF\&B companies (in which little evidence has been found on this topic) formulating the following hypothesis.

$H 4 a / b$. Sustainable strategies have positive/negative impacts on AF\&B companies' profitability in the short-term.

Food production and supply processes have direct and strong impacts on the ecosystems and thus they must undertake significant changes to become more sustainable (Flores-Garcia and Mainar, 2009; Maloni and Brown, 2006). Nevertheless, making the AF\&B business processes sustainable could imply additional costs for the rearrangement of business activities (Guzmán et al., 2011) or it may lead to an increase in efficiency (in terms of resource use and water and energy consumptions), thus inducing costs savings (Chkanikova and Mont, 2015). Moreover, environmental issues cannot be met by single firms, but they require coordinated actions that need to be implemented at the level of supply chains (Fritz and Schiefer, 2008). Indeed, the collaborative relationships ensure an economically sustainable supply chain management that is also fundamental to address the food system's challenges and to achieve better financial performance (Caiazza et al., 2016; Maloni and Brown, 2006).

In the light of this background, we investigate the impact of sustainable business processes on AF\&B companies' short-term profitability through the following hypothesis.

$H 5 a / b$. Sustainable business processes have positive/negative impacts on AF\&B companies' profitability in the short-term.

\section{Data and method}

We developed a cross-sectional time-series analysis on financial and non-financial data of AF\&B global companies, considering a span of ten years. We adopted the panel data analytical approach to account for cultural factors or differences in practices across companies, checking also for those variables that may evolve during the time but not across firms. We limited the study to the 2010-2019 period, analysing the correlations between financial and ESG scrutinized performance in the short-term. Accordingly, we based the sample composition, scanning the Refinitiv Eikon Asset $4{ }^{\circledR}$ database which is one of the rigorous and reliable ESG data providers that collects nonfinancial data for a set of 9,400 listed companies worldwide. Secondly, we obtained annual firm-level financial data from Refinitiv Eikon DatastreamWorldscope widely used in academic studies and market analysis. Therefore, we elaborated an unbalanced panel data, covering 1,760 annual observations from 318 companies net of entities with missing financial data. Notably, the examined companies operate in different countries (cf., Table 1), and they have a market value on average upper than 4 billion Euros.

The following Tables 2 and 3 show respectively the sampling process and the industry distribution of the database used.

Finally, we identified those companies which distinguished as the best and worst sustainability performers annually in the 2010-2019 period. We created such a ranking, focusing on the Refinitiv Eikon Asset $4{ }^{\circledR}$ 's equally weighted ESG overall score annual data series. This score is defined according to companies' self-reported information in the ESG issues identified in Refinitiv (2021). We clustered then each best sustainable company that 


\begin{tabular}{|c|c|c|c|}
\hline Country & $\mathrm{AF} \& \mathrm{~B}$ companies & $\%$ & Sustainable \\
\hline Argentina & 5 & 1.57 & and agri-food \\
\hline Australia & 18 & 5.66 & all agir-100u \\
\hline Belgium & 2 & 0.63 & sector \\
\hline Brazil & 6 & 1.89 & \\
\hline Canada & 9 & 2.83 & \\
\hline Chile & 5 & 1.57 & 321 \\
\hline China & 12 & 3.77 & \\
\hline Colombia & 2 & 0.63 & \\
\hline Denmark & 2 & 0.63 & \\
\hline Finland & 1 & 0.31 & \\
\hline France & 8 & 2.52 & \\
\hline Germany & 2 & 0.63 & \\
\hline Hong Kong & 15 & 4.72 & \\
\hline India & 2 & 0.63 & \\
\hline Indonesia & 4 & 1.26 & \\
\hline Ireland & 2 & 0.63 & \\
\hline Italy & 1 & 0.31 & \\
\hline Japan & 24 & 7.55 & \\
\hline Malaysia & 7 & 2.2 & \\
\hline Mexico & 7 & 2.2 & \\
\hline Netherlands & 4 & 1.26 & \\
\hline New Zealand & 6 & 1.89 & \\
\hline Norway & 4 & 1.26 & \\
\hline Peru & 5 & 1.57 & \\
\hline Philippines & 2 & 0.63 & \\
\hline Poland & 3 & 0.94 & \\
\hline Portugal & 2 & 0.63 & \\
\hline Russia & 1 & 0.31 & \\
\hline Saudi Arabia & 1 & 0.31 & \\
\hline Singapore & 6 & 1.89 & \\
\hline South Africa & 12 & 3.77 & \\
\hline South Korea & 9 & 2.83 & \\
\hline Spain & 3 & 0.94 & \\
\hline Sweden & 2 & 0.63 & \\
\hline Switzerland & 6 & 1.89 & \\
\hline Taiwan & 3 & 0.94 & \\
\hline Thailand & 3 & 0.94 & \\
\hline Turkey & 4 & 1.26 & \\
\hline United Kingdom & 25 & 7.86 & Table 1. \\
\hline United States & 83 & 26.1 & Sample geographical \\
\hline Total & 318 & 100 & distribution \\
\hline Sampling process & & Companies & \\
\hline Refinitiv Eikon A & & 411 & \\
\hline $\mathrm{AF} \& \mathrm{~B}$ companies & & -49 & \\
\hline AF\&B companies & & -44 & Table 2. \\
\hline Final sample & & 318 & Data collection process \\
\hline
\end{tabular}

presents an annual sustainability global score equal to/upper than $50 \%$, creating the "Top" dataset. Differently, we sampled as the worst sustainable companies those firms that present annual overall ESG scores lesser than $50 \%$, creating the "Bottom" dataset. In so doing, we 
BFJ 123,13

\section{2}

Table 3.

Sample industry distribution minimized possible biases related to heterogeneities between the best and worst in class companies at the level of sustainability implementation. Moreover, the analysis performed using two sub-panel data may find different evidence for the same research hypotheses, considering the grade of sustainability principles execution in the study of the ESGP-CFP link. Therefore, the following Table 4 shows the sample distribution per year relating to those companies categorized as best and worst ESG performers.

We designed the analysis, firstly, winsoring each data series at 1 and $99 \%$ levels for every year to eliminate outliers in line with Greene (2003). Secondly, we considered linear associations highlighted by the Pearson test between variables that supposedly may better explain the investigated relationships between ESGP and CFP. Thirdly, we controlled for collinearities to avoid possible biases. Finally, we defined the analytical models to develop our study, finding evidence for assumptions described in Section-2. Accordingly, we performed ordinary least square (OLS) regressions on both predefined panels data, comparing the results produced for "Top" and "Bottom" sampled companies. Each statistical analysis has been performed using STATA software. The present study followed Good Management Theory postulates (Donaldson and Preston, 1995; Preston and O'Bannon, 1997), supposing that if a company efficiently executes sustainability principles, then it achieves higher ESGP which, in turn, may enhance future CFP. In this view, the analysis included in each model the dependent variable (DV) Return on Assets $(R O A)$ such as an accounting-based overall proxy mostly used in prior studies to estimate firms' profitability (e.g. Fischer and Sawczyn, 2013). Moreover, we used well-known Refinitiv Eikon Asset $4{ }^{\circledR}$ scores as independent variables (IVs) that measure how firms perform on multiple macro and micro dimensions characterizing corporate sustainability. Therefore, we used Environmental (ENV_Score), Social (SOC_Score) and Governance (CGV_Score) scores, as independent variables (IVs) that represent macro-categories proxies of sustainability performance. Furthermore, we included as other explanatory variables innovative micro ESG scores (i.e. ProductResp._Score, CSRStrategy_Score, EnvInnovation_Score, Management_Score, ResourceUse_Score) recently released by Refinitiv Eikon which assess specific sustainability corporate issues.

\begin{tabular}{lcr}
\hline Industry & AF\&B companies & $\%$ \\
\hline Beverages & 58 & 18.24 \\
Restaurants, bars and catering & 46 & 14.47 \\
Food producers & 156 & 49.06 \\
Food retail and wholesale & 58 & 18.24 \\
Total & 318 & 100 \\
\hline
\end{tabular}

\begin{tabular}{|c|c|c|c|}
\hline Time & $\begin{array}{c}\text { "Top" panel data } \\
\text { Best ESG performers }\end{array}$ & $\begin{array}{c}\text { "Bottom" panel data } \\
\text { Worst ESG performers }\end{array}$ & Companies yearly observed \\
\hline 2010-2011 & 68 & 87 & 155 \\
\hline 2011-2012 & 66 & 101 & 167 \\
\hline 2012-2013 & 83 & 97 & 180 \\
\hline 2013-2014 & 84 & 104 & 188 \\
\hline $2014-2015$ & 88 & 101 & 189 \\
\hline 2015-2016 & 97 & 124 & 221 \\
\hline 2016-2017 & 110 & 147 & 257 \\
\hline 2017-2018 & 131 & 159 & 290 \\
\hline 2018-2019 & 56 & 57 & 113 \\
\hline Total obs. & 783 & 977 & 1,760 \\
\hline
\end{tabular}

Table 4.

Sample of best/worst examined sustainable companies distributed per years 
The inclusion of these proxies in the analysis also supported us in coherently modelling every equation to investigate the ESGP-CFP relationships along the following dimensions: (1) contribution to healthy and sustainable dietary patterns through products and strategies; (2) socio-environmental sustainability of corporate processes.

Further, we assumed that the ESGP-CFP link works properly if companies own slack resources to activate core business activities and implement sustainability initiatives. Therefore, suitable proxies to estimate absorbed and unabsorbed slack resources (Singh, 1986) have been included in the analysis. Following Bourgeois and Singh (1983), we used accounting metrics that assess different categories of slack resources as control variables (CVs). Notably, we used Overhead Expenses to Net Sales (Overhead_Ratio) measuring absorbed slack resources, while Cash flow to NetSales (CahsFlowSales_Ratio) and Quick ratio (Quick_Ratio) were included in models to assess available slack resources. Further, we assumed that slack resources may moderate the ESGP-CFP interaction as previous studies underscored (e.g. Li et al., 2017; Lin et al., 2019). Finally, we assumed that firm size could affect the ESGP-CFP relationship as previous findings in the literature highlighted (e.g. Callan and Thomas, 2009). We supposed that the largest companies have a high ability to acquire/use slack resources and to innovate their businesses improving sustainability. Contextually, we believe that the bigger is the firm stronger is the stakeholders' call for high standards of ESG and future profitability. Accordingly, we included in the analysis the natural logarithm of Total Assets $(\ln T A)$ that is the CV for firm size (Dang et al., 2018). Furthermore, we used industry dummies (Industry) CVs to check for unobservable time-invariant firm/industryspecific features effects (e.g. firm culture, managerial capabilities, the technology used, competitiveness intensity, etc.) that may affect ESGP-CFP relationships as suggested by previous studies (e.g. Andersen and Dejoy, 2011). Moreover, the analysis used other dummies CVs (i.e. Time) to check also for possible timing effects. Lastly, lagged DV was included in models as another explanatory variable to minimize possible endogeneity effects as suggested by Li (2016). Tables 5 and 6 below respectively describe and report descriptive statistics of variables used in our analysis.

The covariance matrices in Table 7 reports linear association analysis results found using "Top" and "Bottom" panels data which showed dependencies between variables, signs, and intensities. To develop the Pearson correlation test, we considered three levels of statistical significance (i.e. $z<0.01 ; z<0.05 ; z<0.1$ ) and no time lags within the investigated variables.

As for the multicollinearity biases we performed collinearity diagnostics on the group of variables used in models and included them in both "Top" and "Bottom" panels data. We developed this analysis, testing separately macro and micro ESG scores due to their obvious collinearity and ignoring composed variables used to check for moderating effects. Such a test highlighted no multicollinearity effects because all mean Variance Inflation Factors (VIFs) are lesser than two (Allison, 1999). In Table 8 below, we present our analysis models designed in line with what assumed in Section 2, considering the results of both the Pearson correlation and multicollinearity performed tests.

Model-1 checks whether the findings of previous studies are confirmed in our analysis. To this end, we used ENV_Score,SOC_Score, and CGV_Score as IVs, breaking down the ESG overall score. Contextually, Model-1 was defined also to test whether slack resources may moderate the ESGP-CFP link. Models 2-6, instead, analyse the impact of change in peculiar ESGP on firms' profitability. Possible moderating effects produced by slack resources on each interaction between micro-ESGP and firms' profitability were still analysed. Finally, every equation considered one-year lag (i.e. $n=1$ year) between the predictor and the other explanatory variables to better appreciate possible short-term impacts in the scrutinized relationships, also minimizing possible endogeneity effects $(\mathrm{Li}, 2016)$. The following section presents and discusses the study's main results.
Sustainable development and agri-food sector

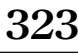


BFJ
123,13

\begin{tabular}{|c|c|c|}
\hline & $R O A$ & It is an accounting profitability ratio largely used to assess how a company efficiently \\
\hline & ENV_Score & $\begin{array}{l}\text { It measures the company's impacts on ecosystems, reflecting how well a company } \\
\text { uses management practices minimizing environmental risks and generating long- } \\
\text { term stakeholder value }\end{array}$ \\
\hline 324 & SOC_Score & $\begin{array}{l}\text { It reflects a company's capacity to generate trust and loyalty with its stakeholders } \\
\text { implementing best management practices }\end{array}$ \\
\hline & CGV_Score & $\begin{array}{l}\text { It assesses how management and governance systems act in the best interests of long- } \\
\text { term stakeholders' expectations }\end{array}$ \\
\hline & ProductResp._Score & $\begin{array}{l}\text { It reflects a company's capacity to produce quality goods and services integrating the } \\
\text { customer's health and safety, integrity, and data privacy }\end{array}$ \\
\hline & CSRStrategy_Score & $\begin{array}{l}\text { It estimates how companies integrate both the financial and ESG factors into their } \\
\text { decision-making processes }\end{array}$ \\
\hline & EnvInnovation_Score & $\begin{array}{l}\text { It assesses the corporate capacity to reduce the environmental costs and burdens, } \\
\text { creating new market opportunities through innovative technologies and processes or } \\
\text { eco-designed products }\end{array}$ \\
\hline & Management_Score & $\begin{array}{l}\text { It measures the commitment and effectiveness of the company to following best } \\
\text { sustainability practices and good corporate governance principles }\end{array}$ \\
\hline & ResourceUse_Score & $\begin{array}{l}\text { It reflects the corporate performance and capacity to reduce the resources use and to } \\
\text { find more eco-efficient solutions in production and supply chain management } \\
\text { processes }\end{array}$ \\
\hline & Overhead_Ratio & $\begin{array}{l}\text { It evaluates the operating costs of doing business compared to the company's } \\
\text { revenues, and those slack resources that have already been absorbed as excess costs } \\
\text { (Bourgeois and Singh, 1983) }\end{array}$ \\
\hline & CahsFlowSales_Ratio & $\begin{array}{l}\text { It measures the corporate capacity to generate cash flow from its sales volume, and the } \\
\text { company's attitude to generate operational slack resources suitable to the business } \\
\text { development (Bourgeois and Singh, 1983) }\end{array}$ \\
\hline & Quick_Ratio & This liquidity ratio measures those current assets available to cover current liabilities, \\
\hline ion of & & \\
\hline $\begin{array}{l}\text { variables used in the } \\
\text { analysis }\end{array}$ & $\ln T A$ & $\begin{array}{l}\text { Total assets is an accounting-based firms' size measure computed in the logarithmic } \\
\text { form to normalize data }\end{array}$ \\
\hline
\end{tabular}

\section{Results and discussions}

Empirical results of our analysis performed using annual observations in "Top" and "Bottom" panels data are shown in the following Tables 9 and 10.

The first regressions performed using Model-1 showed positive relationships between corporate sustainability and firms' profitability in the short-term, mostly when the analysis considered companies included in the best ESG performers' sample. This evidence supports what assumed in H1a and prior studies' findings (e.g. Acar et al., 2019; Fisher and Sawczyn, 2013; Orlitzky et al., 2003). Notably, we found that both $E N V_{-} S_{c o r e}{ }_{t-1}, S_{S O C S C o r e}{ }_{t-1}$, and $C G V_{-}$Score $_{t-1}$ are in positive correlation with $R O A_{t}$, using " $T o \bar{p}$ " panel data. Accordingly, we may assume that companies with average-highest sustainability standards may enhance future CFP in the short-run. On the other hand, the analysis highlighted that eco-friendly corporate activities and the management commitment to sustainability affect negatively the one-year lagged $R O A$, especially for those companies with lesser ESGP. These findings are in line with those of Nirino et al. (2019) and support H1b. We presume that the negative correlation between environmental sustainability and firms' profitability is due to the following reasons. Firstly, lesser sustainable companies need to invest in eco-friendly technologies and improve their ESGP, but this approach penalizes short-term profitability. Notably, sustainability investments produce their financial and non-financial effects in the 


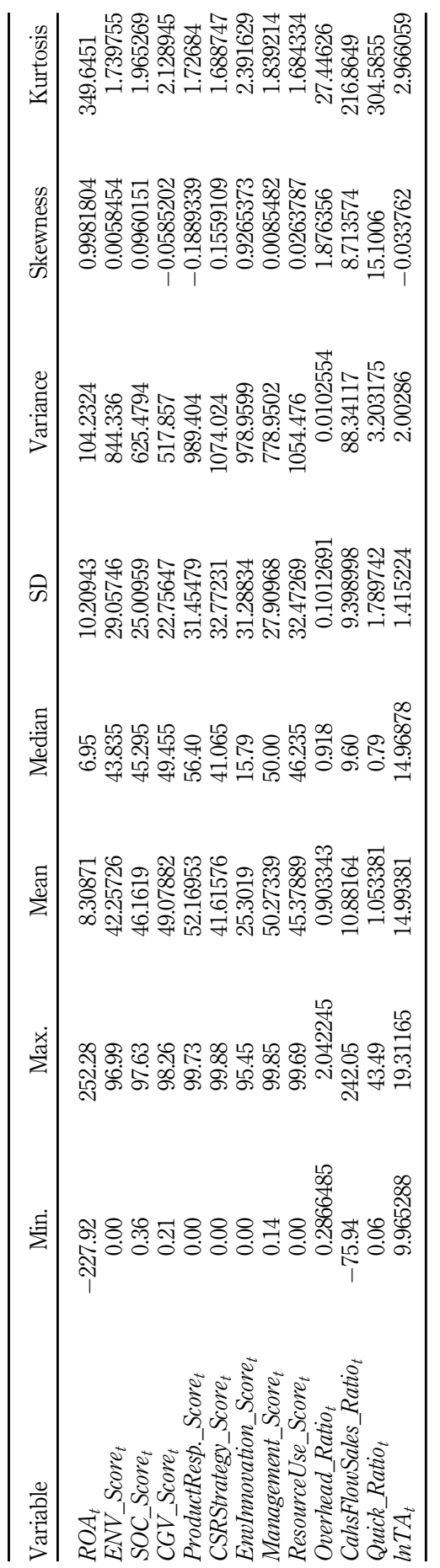

Sustainable development and agri-food sector

325

Table 6. Descriptive statistics 
BFJ
123,13

326

Table 7.

Pearson correlation and collinearity diagnostics results using the "top" and "bottom" panels data

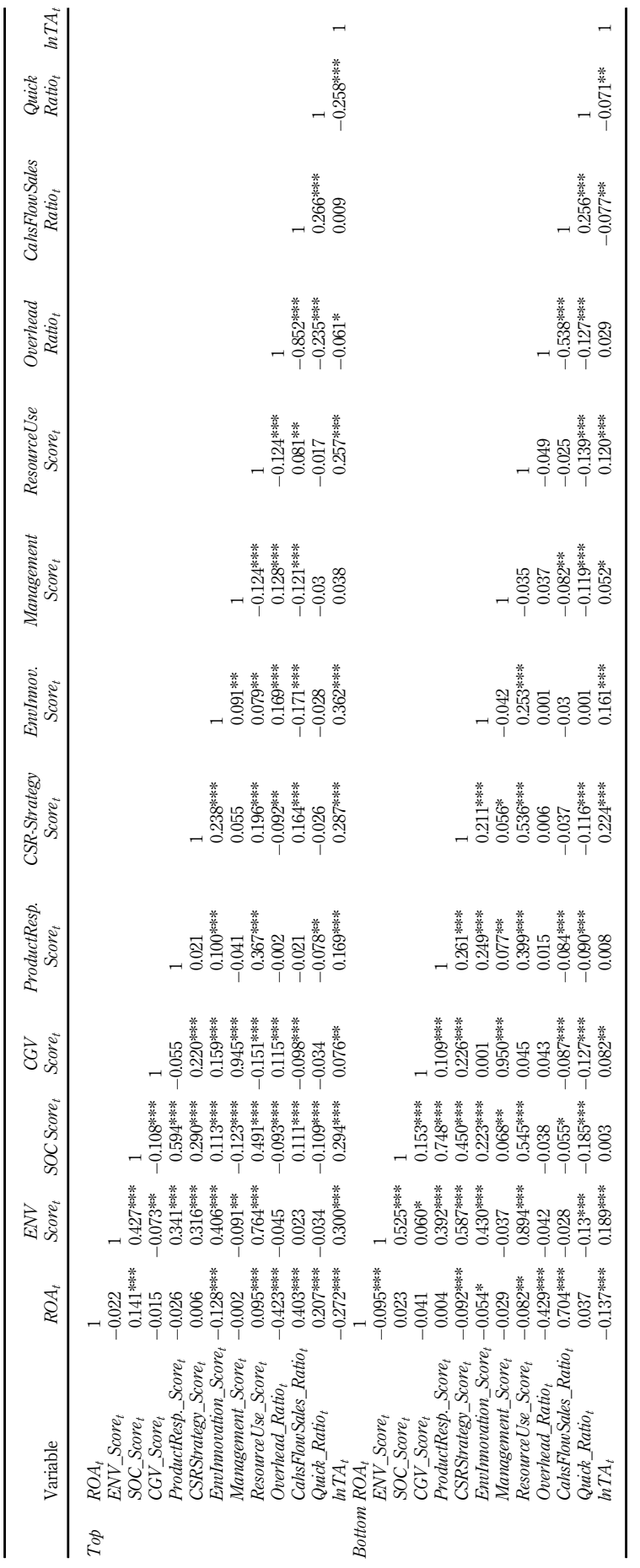




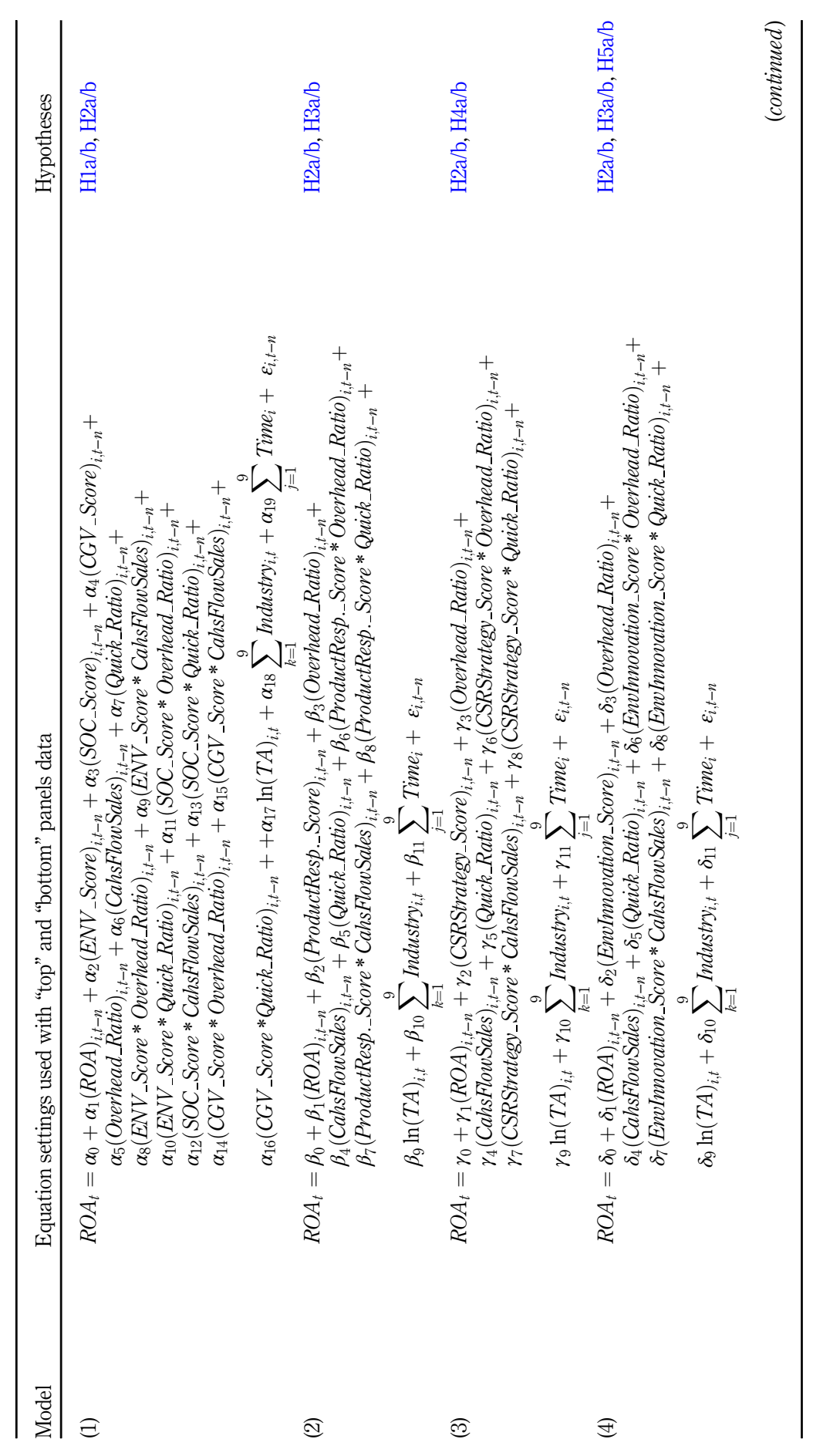

Sustainable development and agri-food sector 327

Table 8. Analytical models 


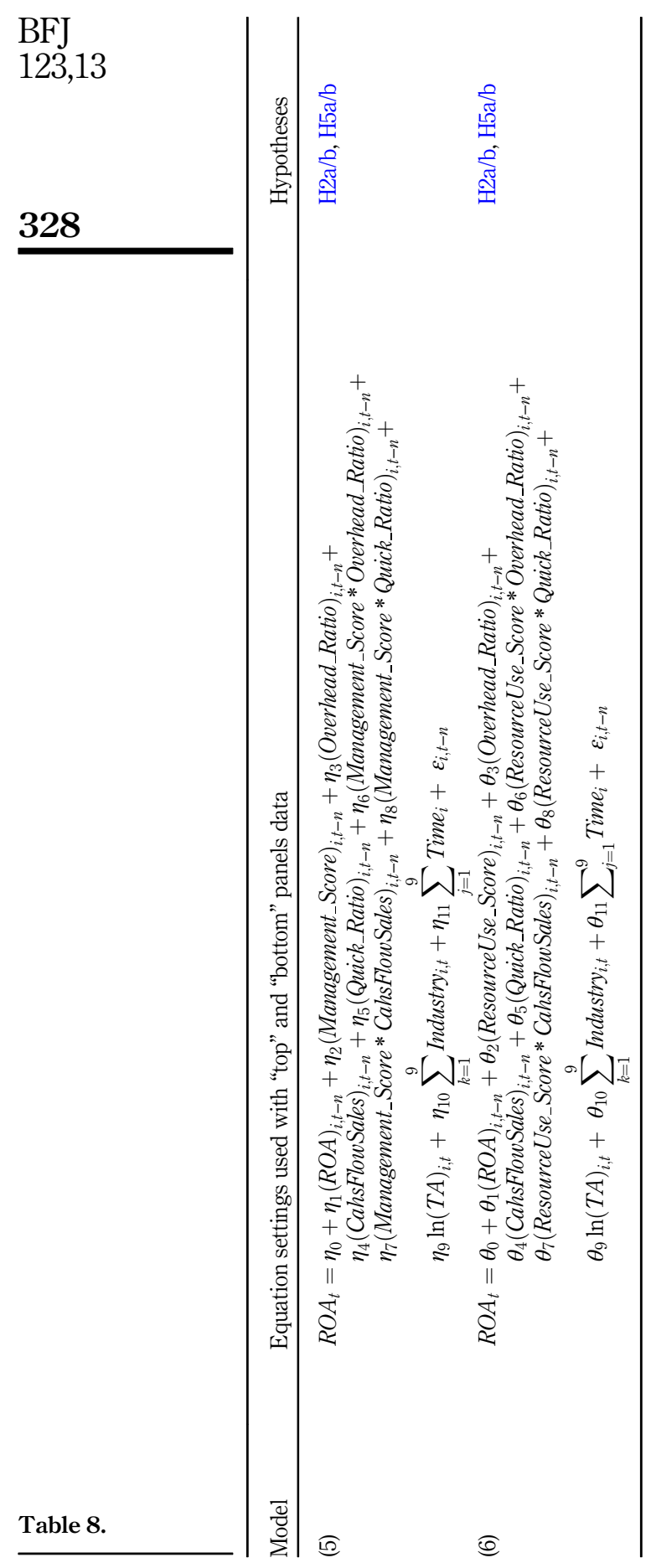




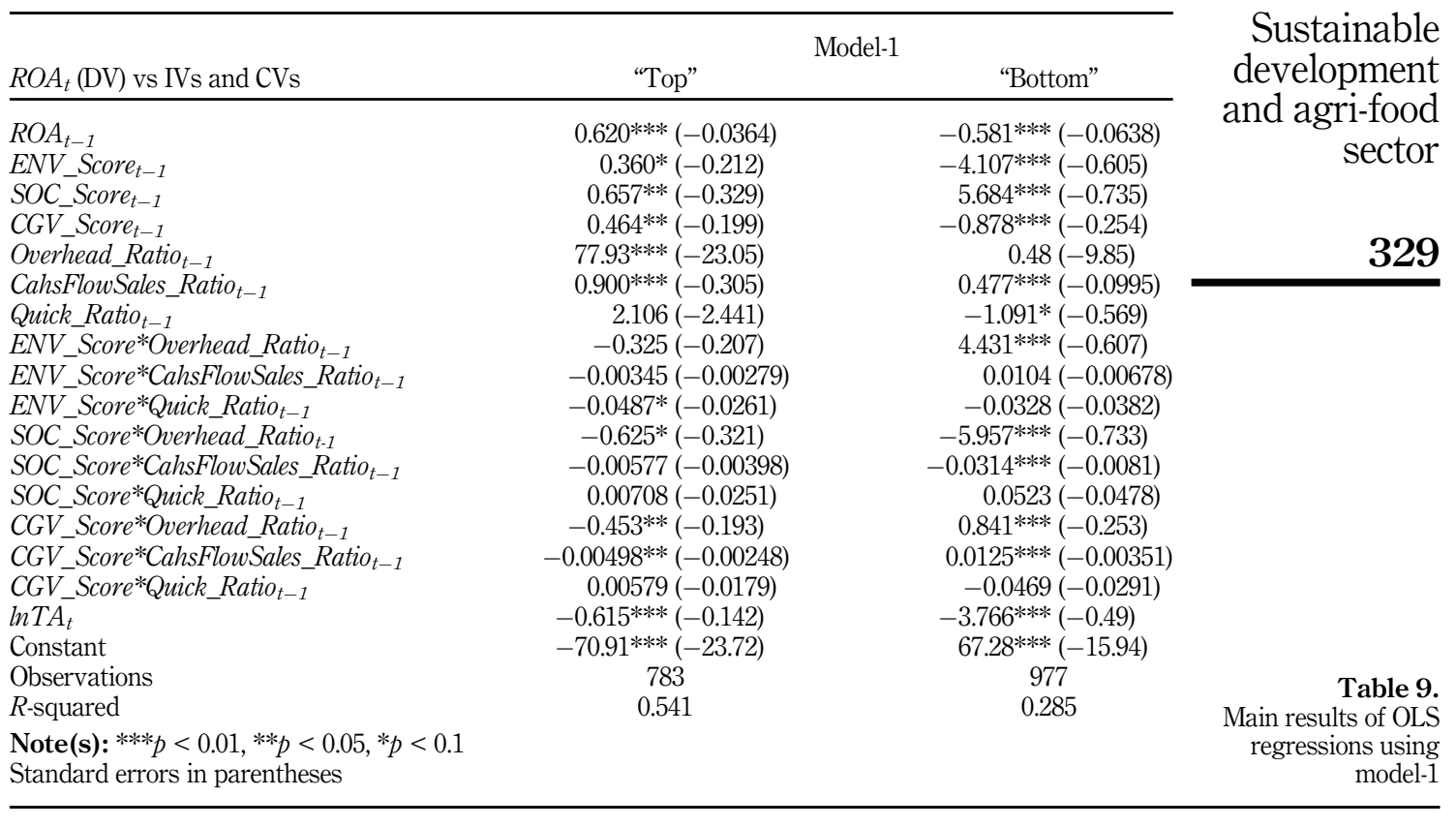

mid and long-term, thus this in turn negatively affects profitability shortly. Secondly, companies with lower environmental sustainability standards may fail to attract investors, retain customers, or engage other stakeholders, losing profitability in the short-term. As regards, instead, the negative relationship between the management commitment to sustainability and firms' profitability found for companies lesser ESG performers, we assume the following motivation. Companies that are approaching sustainability or that should improve their lower ESGP, contextually allocate resources to implement managerial systems, practices and mechanisms ensuring the execution and control of those activities which foster long-term stakeholder value creation. Therefore, this may penalize $R O A$ shortly, but in the long-term, it may boost both financial and non-financial performance only if the company reaches mid-higher ESGP. Differently, results showed that corporate social sustainability is in positive correlation with CFP, focusing on the worst sustainable companies' sample. This result confirms what assumed in H1a and previous studies' evidence (e.g. Nirino et al., 2019; Gangi et al., 2020). We presume that this positive relationship is due to the nature of social sustainability activities which do not need strong investment as environmental ones and concurrently produce immediate both financial returns and higher ESGP (Nirino et al., 2019). Moreover, results of regressions on both panels data highlighted moderating effects of slack resources on ESGP and CFP relationship, supporting both $\mathrm{H} 2 \mathrm{a} / \mathrm{b}$, and confirming prior studies' mixed results (e.g. Li et al., 2017; Lin et al., 2019). Notably, we found negative and significant moderating effects that absorbed slack resources produced on ESGP-CFP link. Further, results showed that the interaction between environmental sustainability and firms' profitability is negatively moderated by financial available slack resources. Finally, the analysis highlighted that operational slack resources negatively moderate the relationship between the management to sustainability and CFP. Furthermore, we found slack resources' mediating effects on the ESGP-CFP link, also considering companies' sample with lower sustainability performance. Notably, the analysis highlighted that absorbed slack resources positively moderate the interaction between environmental sustainability and CFP, 


\section{$\mathrm{BFJ}$ \\ 123,13}

330

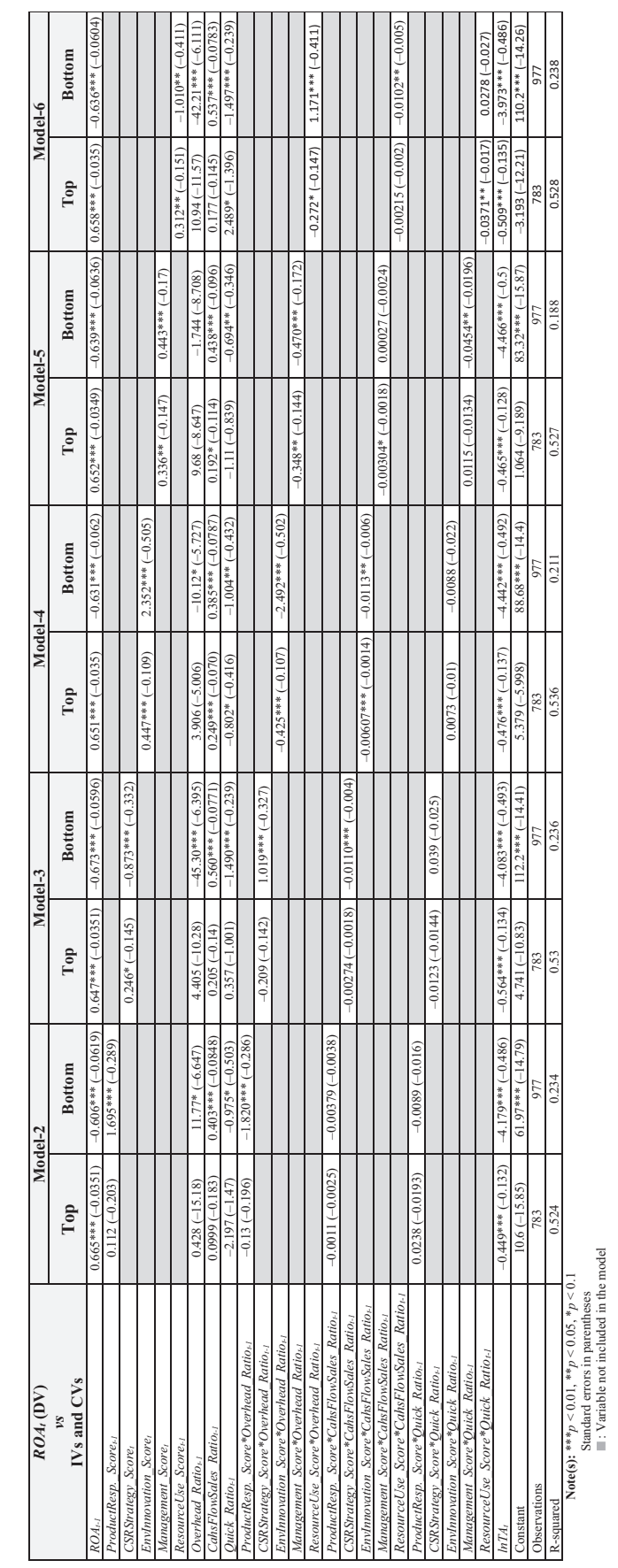

Table 10.

Main results of OLS

regressions using

models 2-6 
confirming H2a. At the same time, we found positive moderating effects of absorbed slack resources on the link between the management commitment to sustainability and firms' profitability, supporting H2a. Differently, findings highlighted that the operational available slack resources negatively moderate the interaction between social sustainability and CFP, supporting H2b. Moreover, results showed that operational available slack resources produce positive moderating effects on the relationship between social sustainability and CFP, confirming H2a. Contextually, we found that the operational available slack resources negatively moderate the relationship between social sustainability and firms' profitability, supporting H2b. Regressions on Model-2 using "Top" panel data did not produce any significant results that support $\mathrm{H} 3 \mathrm{a} / \mathrm{b}$ and $\mathrm{H} 2 \mathrm{a} / \mathrm{b}$. We found, instead, some evidence in line with the related research hypotheses, using "Bottom" panel data and the same model. Notably, the analysis showed that firms' profitability is in positive correlation with the corporate commitment that aims to preserve the consumers' health and safety, as well as customers' integrity and data privacy, selling higher quality standard products. Therefore, this evidence contrasts some prior studies' insights (e.g. Ingenbleek, 2015), and it supports H3a. Accordingly, we may assume that companies which need to enhance their ESGP, they should arrange products quality in line with customers' new expectations as regard sustainability, healthy, and safety, so to achieve competitive advantages and higher shortterm profitability. This strategic approach, indeed, has been adopted by the best sustainable companies which probably reached, in turn, their market positioning through the promotion of higher product sustainability and quality standards. Moreover, results showed that absorbed slack resources negatively moderate the relationship between ProductResp._Score ${ }_{t-1}$ and $R O A_{t}$, confirming $\mathrm{H} 2 \mathrm{~b}$ and prior studies' findings (e.g. Li et al., 2017). Regressions carried out using Model-3 highlighted that the integration of sustainability principles in strategy and management system positively affects the one-year lagged corporate profitability for those companies which usually perform higher ESGP. This evidence supports thus H4a, and it is in line with prior studies' results (e.g. Bodhanwala and Bodhanwala, 2018). Differently, results showed that including ESG issues in strategy and management activities may penalize the short-term firms' profitability for lesser sustainable companies. These findings are in line with $\mathrm{H} 4 \mathrm{~b}$, confirming the stream of literature that argues for a negative relationship between CSRstrategy and CFP (e.g. Folajin et al., 2014). We may assume that this negative relationship is due to some difficulties which a company that approaches ESG issues or a sustainability beginner faces in the short-term. In this regard, companies need time to integrate ESG factors in decision-making processes and systems so to achieve positive results on firms' profitability and sustainability performance over time. Moreover, we found moderating effects only in the case of worst sustainable companies of slack resources between CSRStrategy_Score $t_{-1}$ and $R O A_{t}$, supporting respectively $\mathrm{H} 2 \mathrm{a} / \mathrm{b}$. Notably, the analysis highlighted that absorbed slack resources positively moderate that ESGP-CFP link, while operational available slack resources produce negative moderating effects on the same relationship. Regressions using Model-4 highlighted that product and processes environmental innovation activities positively affect CFP for both best and worst sustainable companies. This evidence supports H3a and H5a, confirming previous studies' insights (e.g. Chkanikova and Mont, 2015). Notably, analysing regression coefficients, we may assume that the innovation is a cross-cutting driver involving products, processes, and supply chain management and useful to improve financial and nonfinancial firms' performance. Therefore, the implementation of eco-innovations is key to foster sustainability even boosting corporate profitability, especially for those companies which need to improve their ESGP. As for moderating effects, all the analysis highlighted that absorbed and operational available slack resources negatively moderate the link between sustainability and firms' profitability. These results confirm $\mathrm{H} 2 \mathrm{~b}$, as well as prior studies' findings (e.g. Li et al., 2017). Regressions on Model-5 showed that the firms' short-term profitability is positively affected by the managerial commitment to sustainability also
Sustainable development and agri-food sector 
BFJ

123,13

executing good corporate governance principles. These findings support H5a. The analysis highlighted such evidence for both best and worst sustainable companies' samples. Therefore, in the light of such a result, we may state that the managerial commitment towards sustainability and good corporate governance are required drivers to boost both ESGP and corporate profitability shortly. Further, we found evidence for H2b. Notably, regressions highlighted that absorbed slack resources moderate negatively the interaction between Management_Score ${ }_{t-1}$ and $R O A_{t}$, considering both the best and worst companies' samples. Contextually, the analysis highlighted for the best sustainable companies that operational available slack resources negatively moderate the relationship between the managerial commitment to sustainability and towards the implementation of good governance. Furthermore, we found that financial available slack resources also may negatively moderate the same link in the case of the worst sustainable companies. Finally, regressions on Model-6 using "Top" panel data showed that the short-term firms' profitability is positively affected by the corporate capability in rationalising natural resources and fostering sustainability along the supply chain. This evidence supports H5a, as well as it is in line with prior studies (e.g. Maloni and Brown, 2006). Moreover, the analysis showed that absorbed and financial available slack resources negatively moderate the relationship between ResourceUse_Score $t_{-1}$ and $R O A_{t}$. These results confirm H2b. On the other hand, the analysis highlighted that scarcely sustainable companies may suffer from a reduction in their shortterm profitability, despite efforts boosting the sustainable management of resources and supply chain. This finding is in line with H5b. In the light of such evidence, we may presume the following reasons. Companies with lesser ESGP need to invest in fostering efficiently the management of natural resources in production processes and along their supply chain. This approach in turn penalizes the short-term firms' profitability. Moreover, lesser sustainable companies may have weakly routinized practices that efficiently manage natural resources in production and supply chain activities. Therefore, such a gap may negatively affect also corporate profitability. Further, we found that absorbed slack resources produce positive moderating effects on the ResourceUse_Score $t_{-1}$ and $R O A_{t}$ link, while the operational available slack resources negatively moderate the same relationship. These results support $\mathrm{H} 2 \mathrm{a} / \mathrm{b}$. Lastly, all performed regressions highlighted that slack resources critically affect corporate short-term profitability. Further, results showed that firms' size negatively affects $R O A_{t}$, while industry and timing generally did not show significant effects.

\section{Conclusions}

This study examined the ESGP-CFP link in AF\&B industry, contributing to the present literature in several ways. Firstly, it is among the first studies that deepened the relationship between sustainability and the AF\&B companies' short-term profitability. Therefore, we found that corporate sustainability represents a benefit for those companies that are the best ESG performers, while it may be costly for the others. Notably, our results highlighted that sustainability enhances future CFP. These findings confirm Gangi et al. (2020) insights, while partially contrast those of Nirino et al. (2019). Differently, results performed using "Bottom" panel data showed that only social sustainability positively affects CFP, confirming Nirino et al. (2019) findings, while prior improvements in environmental and governance performance are detrimental for the firms' profitability in the short-term, in line with scholars advocating the shareholder perspective (e.g. López et al., 2007; Hillman and Keim, 2001). Secondly, adopting an original analytical approach, we decomposed corporate sustainability in its multiple micro dimensions (i.e. management commitment, strategy, product, and processes) to examine whether and how improvements in peculiar ESGP aspects may affect CFP. Notably, we found different evidence respectively for best and worst ESG performers. The analysis showed that improvements in sustainable processes, CSR 
strategy, management commitment, and good corporate governance produce positive impacts on the best sustainable companies' CFP in the short-term. This partially confirms the insights of Acar et al. (2109), Bodhanwala and Bodhanwala (2018), Chkanikova and Mont (2015) and Gangi et al. (2020). Conversely, for the lesser sustainable AF\&B companies, we found a negative effect of CSR strategy and sustainable production/supply chain management on short-term CFP. These findings are in line with Boyle et al. (1997), and Folajin et al. (2014) as well as partially contrast the insights of Bodhanwala and Bodhanwala (2018), and Maloni and Brown (2006). However, these negative effects can be mitigated by other sustainability initiatives such as responsible products, eco-innovation, and management commitment to sustainability, which have shown positive effects on shortterm CFP. Accordingly, we theoretically highlight that sustainability becomes profitable under certain conditions. Notably, companies need to consolidate sustainability management fostering a real managerial commitment and becoming at the forefront in addressing ESG issues (Vitale et al., 2019). When companies approach sustainability for the first time or implement isolated initiatives without a real managerial commitment, sustainability can be detrimental to CFP. Therefore, our evidence contributes to Good Management Theory (e.g. Waddock and Graves, 1997). We showed that sustainability can be profitable depending on the degree of efforts on specific and crucial ESG factors. As for moderating effects of slack resources on the scrutinized relationship, we found that such variables critically affect the ESGP-CFP link, but our analysis produced mixed results as previous studies (e.g. Li et al., 2017; Lin et al., 2019). Our results corroborate the need of breaking down AF\&B companies' sustainability into its multiple aspects to better appreciate all firms' performance and their mutual interdependencies, in line with what also developed by recent international initiatives (e.g. Fixing The Business of Food; Food and Agriculture Benchmark). Finally, this paper provides the following practical implications. To reinforce the ESGP-CFP relationship in the short-term, the best sustainable companies should focus on CSR strategy, environmental innovation, managerial commitment and good corporate governance, as well as efficiency in resource use. As for worst sustainable companies, managers should prioritize efforts boosting responsible products, eco-innovation, and management commitment towards sustainability to enhance short-term firms' profitability. Accordingly, implementing activities on these ESG issues may also foster firms' sustainability commitment over time. Differently, managers must not discourage if companies may achieve shortly financial losses executing some sustainability initiatives such as the implementation of CSR strategy, the efficient use of resources in production processes, and the sustainable supply chain management. These ESG topics may penalize CFP in the short-term but they may help companies to enhance sustainability standards as well as the firm's profitability in the longterm (as demonstrated by the best sustainable AF\&B companies). In the wake of our study, we invite other scholars to deepen the ESGP-CFP link in the AF\&B sector also focusing on other possible sustainability aspects, enlarging companies' sample and the period analysed, as well as adopting other statistical techniques (e.g. Partial Least Squares Structural Equation Modeling, Dynamic Panel Data, etc.).

\section{References}

Acar, M.F., Aktas, E., Agan, Y. and Bourlakis, M. (2019), "Does sustainability pay? Evidence from the food sector", Journal of Foodservice Business Research, Vol. 22 No. 3, pp. 239-260, doi: 10.1080/ 15378020.2019.1597672.

Agusti-Perez, M., Galan, J.L. and Acedo, F.J. (2020), "Relationship between slack resources and performance: temporal symmetry and duration of effects", European Journal of Management and Business Economics, Vol. 29 No. 3, pp. 255-275, doi: 10.1108/EJMBE-10-2019-0177.
Sustainable development and agri-food sector

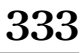


BFJ 123,13

\section{4}

Allison, P.D. (1999), Multiple Regression: A Primer, Pine Forge Press, Thousand Oaks, California and London, 0761985336.

Andersen, M.L. and Dejoy, J.S. (2011), "Corporate social and financial performance: the role of size, industry, risk, R\&D and advertising expenses as control variables", Business Society Review, Vol. 116, pp. 237-256, doi: 10.1111/j.1467-8594.2011.00384.x.

Augustin, M.A., Riley, M., Stockmann, R., Bennett, L., Kahl, A., Lockett, T., Osmond, M., Sanguansri, P., Stonehouse, W., Zajac, I. and Cobiac, L. (2016), "Role of food processing in food and nutrition security", Trends in Food Science and Technology, Vol. 56, pp. 115-125, doi: 10.1016/j.tifs.2016. 08.005 .

Bodhanwala, S. and Bodhanwala, R. (2018), "Does corporate sustainability impact firm profitability? Evidence from India”, Management Decision, Vol. 56 No. 8, pp. 1734-1747, doi: 10.1108/MD-042017-0381.

Bourgeois, L.J., III (1981), "On the measurement of organizational slack", Academy of Management Review, Vol. 6 No. 1, pp. 29-39, doi: 10.2307/257138.

Bourgeois, L. and Singh, J. (1983), "Organizational slack and political behavior among top management teams", Academy of Management Proceedings, Vol. 1983 No. 1, pp. 43-49, doi: 10.5465/ambpp.1983.4976315.

Boyle, E.J., Higgins, M.M. and Rhee, G.S. (1997), "Stock market reaction to ethical initiatives of defense contractors: theory and evidence", Critical Perspectives on Accounting, Vol. 8 No. 6, pp. 541-561, doi: 10.1006/cpac.1997.0124.

Brammer, S., Brooks, C. and Pavelin, S. (2006), "Corporate social performance and stock returns: UK evidence from disaggregate measures”, Financial Management, Vol. 35 No. 3, pp. 97-116, doi: 10. 1111/j.1755-053X.2006.tb00149.x.

Broccardo, L. and Zicari, A. (2020), "Sustainability as a driver for value creation: a business model analysis of small and medium enterprises in the Italian wine sector", Journal of Cleaner Production, Vol. 259, 120852, doi: 10.1016/j.jclepro.2020.120852.

Caiazza, R., Volpe, T. and Lawley, M. (2016), "Creating value chains: the role of relationship development", British Food Journal, Vol. 118 No. 6, pp. 1384-1406, doi: 10.1108/BFJ-102015-0389.

Callan, S.J. and Thomas, J.M. (2009), "CFP and corporate social performance: an update and reinvestigation", Corporate Social Responsibility and Environmental Management, Vol. 16 No. 2, pp. 61-78, doi: 10.1002/csr.182.

Chkanikova, O. and Mont, O. (2015), "Corporate supply chain responsibility: drivers and barriers for sustainable food retailing", Corporate Social Responsibility and Environmental Management, Vol. 22 No. 2, pp. 65-82, doi: 10.1002/csr.1316.

Coppola, A. and Ianuario, S. (2017), "Environmental and social sustainability in producer organizations' strategies”, British Food Journal, Vol. 119 No. 8, pp. 1732-1747, doi: 10.1108/ BFJ-11-2016-0553.

Dang, C., Li, F. and Yang, C. (2018), "Measuring firm size in empirical corporate finance", Journal of Banking and Finance, Vol. 86, pp. 159-176, doi: 10.1016/j.jbankfin.2017.09.006.

Donaldson, T. and Preston, L.L. (1995), "The stakeholder theory of the corporation: concepts, evidence, and implications", Academic Management Review, Vol. 20 No. 1, pp. 65-91, doi: 10.5465/amr. 1995.9503271992.

Fischer, T.M. and Sawczyn, A.A. (2013), "The relationship between corporate social performance and CFP and the role of innovation: evidence from German listed firms", Journal of Management Control, Vol. 24 No. 1, pp. 27-52, doi: 10.1007/s00187-013-0171-5.

Flores-Garcia, M. and Mainar, A.J. (2009), "Environmental effects of production and consumption activities within an economy: the Aragon case", International Advances in Economic Research, Vol. 15 No. 4, pp. 437-455, doi: 10.1007/s11294-009-9229-4. 
Folajin, O.O., Ibitoye, O.T. and Dunsin, A.T. (2014), "Corporate social responsibility and organizational profitability: an empirical investigation of United Bank for Africa (UBA) Plc", International Journal of Academic Research in Business and Social Sciences, Vol. 4 No. 8, pp. 205-214, doi: 10. 6007/IJARBSS/v4-i8/1089.

Food and Agriculture Organization of the United Nations (FAO) (2017), The Future of Food and Agriculture: Trends and Challenges, available at: http://www.fao.org/3/a-i6583e.pdf (assessed 13 January 2021).

Freeman, R.E. (1984), Strategic Management: A Stakeholder Approach, Pitman Publishing, Boston.

Sustainable development and agri-food sector

Friedman, M. (1970), "A Friedman doctrine: the social responsibility of business is to increase its profits”, The New York Times Magazine, Vol. 13, pp. 32-33.

Fritz, M. and Schiefer, G. (2008), "Food chain management for sustainable food system development: a European research agenda", Agribusiness: An International Journal, Vol. 24 No. 4, pp. 440-452, doi: 10.1002/agr.20172.

Gangi, F., D’Angelo, E., Daniele, L.M. and Varrone, N. (2020), “The impact of corporate governance on social and environmental engagement: what effect on firm performance in the food industry?", British Food Journal, Vol. 123 No. 2, pp. 610-626, doi: 10.1108/BFJ-02-2020-0140.

Greene, W.H. (2003), Econometric Analysis, Prentice-Hall, Englewood Cliffs, New Jersey, 0-13-066189-9.

Guzmán, G.I., González de Molina, M. and Alonso, A.M. (2011), "The land cost of agrarian sustainability: an assessment", Land Use Policy, Vol. 28 No. 4, pp. 825-835, doi: 10.1016/j. landusepol.2011.01.010.

Hillman, A.J. and Keim, G.D. (2001), "Shareholder value, stakeholder management and social issues: what's the bottom line?", Strategic Management Journal, Vol. 22 No. 2, pp. 125-139, doi: 10.1002/ 1097-0266(200101)22:2<125::AID-SMJ150>3.0.CO;2-H.

Ingenbleek, P.T.M. (2015), "Price strategies for sustainable food products", British Food Journal, Vol. 117 No. 2, pp. 915-928, doi: 10.1108/BFJ-02-2014-0066.

Li, F. (2016), "Endogeneity in CEO power: a survey and experiment", Investment Analysts Journal, Vol. 45 No. 3, pp. 149-162, doi: 10.1080/10293523.2016.1151985.

Li, D., Cao, C. and Zhao, Y. (2017), "Effects of corporate environmental responsibility on financial performance: the moderating role of government regulation and organizational slack", Journal of Cleaner Production, Vol. 166, pp. 1323-1334.

Lin, W.L., Ho, J.A., Ng, S.I. and Lee, C. (2019), "Does corporate social responsibility lead to improved firm performance? The hidden role of financial slack", Social Responsibility Journal, Vol. 16 No. 7, pp. 957-982, doi: 10.1108/SRJ-10-2018-0259.

López, M.V., Garcia, A. and Rodriguez, L. (2007), "Sustainable development and corporate performance: a study based on the Dow Jones sustainability index", Journal of Business Ethics, Vol. 75 No. 3, pp. 285-300, doi: 10.1007/s10551-006-9253-8.

Maloni, M.J. and Brown, M.E. (2006), "Corporate social responsibility in the supply chain: an application in the food industry", Journal of Business Ethics, Vol. 68 No. 1, pp. 35-52, doi: 10. 1007/s10551-006-9038-0.

McWilliams, A., Siegel, D.S. and Wright, P.M. (2006), "Corporate social responsibility: strategic implications", Journal of Management Studies, Vol. 43 No. 1, pp. 1-18, doi: 10.1111/j.1467-6486. 2006.00580.x.

Morioka, S.N. and Carvalho, M.M. (2016), "Measuring sustainability in practice: exploring the inclusion of sustainability into corporate performance systems in Brazilian case studies", Journal of Cleaner Production, Vol. 136, pp. 123-133, doi: 10.1016/j.jclepro.2016.01.103.

Nirino, N., Miglietta, N. and Salvi, A. (2019), "The impact of corporate social responsibility on firms' financial performance, evidence from the food and beverage industry", British Food Journal, Vol. 1 No. 1, pp. 15-29, doi: 10.1108/BFJ-07-2019-0503. 
BFJ 123,13

Orlitzky, M., Schmidt, F.L. and Rynes, S.L. (2003), "Corporate social and financial performance: a metaanalysis”, Organization Studies, Vol. 24 No. 3, pp. 403-441, doi: 10.1177/0170840603024003910.

Preston, L.E. and O'Bannon, D.P. (1997), "The corporate social-financial performance relationship: a typology and analysis", Business and Society, Vol. 36 No. 4, pp. 419-429, doi: 10.1177/ 000765039703600406.

Refinitiv (2021), "Environmental, social and governance (ESG) scores from Refinitiv", February 2021, available at: https:/www.refinitiv.com/content/dam/marketing/en_us/documents/methodology/ refinitiv-esg-scores-methodology.pdf (accessed 8 February 2021).

Singh, J. (1986), "Performance slack and risk taking in organizational decision making", Academy of Management Journal, Vol. 29 No. 3, pp. 562-585, doi: 10.5465/256224.

Vitale, G., Cupertino, S., Rinaldi, L. and Riccaboni, A. (2019), "Integrated management approach towards sustainability: an Egyptian business case study", Sustainability, Vol. 11 No. 5, p. 1244, doi: 10.3390/su11051244.

Waddock, S.A. and Graves, S.B. (1997), "The corporate social performance-financial performance link", Strategic Management Journal, Vol. 18 No. 4, pp. 303-319, doi: 10.1002/(SICI)10970266(199704)18:4<303::AID-SMJ869>3.0.CO;2-G.

Wiek, A. and Weber, O. (2014), "Sustainability challenges and the ambivalent role of the financial sector", Journal of Sustainable Finance and Investment, Vol. 4 No. 1, pp. 9-20, doi: 10.1080/ 20430795.2014.887349.

Xu, E., Yang, H., Quan, J.M. and Lu, Y. (2015), “Organizational slack and corporate social performance: empirical evidence from China's public firms", Asia Pacific Journal of Management, Vol. 32 No. 1, pp. 181-198, doi: 10.1007/s10490-014-9401-0.

\section{Corresponding author}

Sebastiano Cupertino can be contacted at: cupertino@unisi.it

For instructions on how to order reprints of this article, please visit our website:

www.emeraldgrouppublishing.com/licensing/reprints.htm

Or contact us for further details: permissions@emeraldinsight.com 